\title{
Self or other: Directors' attitudes towards policy initiatives for external board evaluation
}

\author{
Rebecca Booth $^{\mathrm{a}}$ and Donald Nordberg ${ }^{\mathrm{b}}$ *
}

\begin{abstract}
Recurrent crises in corporate governance have created policy pressure for greater attention to the effectiveness of boards. Since the 1990s there have been calls for boards to undertake regular self-evaluation. Since 2010, the UK Corporate Governance Code has urged large corporations to engage outside parties to conduct such appraisals at least every three years, a move other jurisdictions have copied. Despite its importance, little research has been conducted into processes or outcomes of board evaluation. This study explores the attitudes of directors on board evaluation, whether self-administered or facilitated by others. We interviewed 17 directors with some 50 listed-company board appointments between them. Even though their companies fall below the threshold specified in policy, all undertake board self-evaluations and evaluations using professional facilitators. We find broad acceptance of the principle and recognition of the value of board evaluation. We also find some acceptance amongst those directors who have implemented external evaluation of the benefits of using outside facilitators. Their evaluation of the evaluation process points towards a need to professionalise the practice of outside facilitation, and to conduct research into the skills and knowledge needed and the processes used.
\end{abstract}

Keywords: Board evaluation, external facilitation, directors, corporate governance

This paper has been accepted for delivery to the conference of the International Corporate Governance Society in Rome, September 2017

*corresponding author: donald@ nordberg.org.uk

\footnotetext{
${ }^{a}$ Rebecca Booth is a financial services professional working in the British Channel Islands. She earned an MSc in Corporate Governance from Bournemouth University.

${ }^{b}$ Donald Nordberg is Associate Professor of Strategy and Corporate Governance at Bournemouth University. His research has been published in journals including Corporate Governance: An International Review, Business History, European Management Journal, Business Ethics: A European Review, and Journal of Financial Regulation \& Compliance. He was educated at the University of Illinois at Urbana-Champaign, the University of Warwick and the University of Liverpool.
} 


\section{Introduction}

In the wake of the corporate governance failings in the early 2000s, policy in many countries has pushed for corporations to conduct regular and systematic reviews of the performance of their boards of directors. Many companies complied: some boards conducted self- and peer-evaluation; at others the chair conducted more or less formal appraisal of fellow directors and the board as a whole. Following the financial crisis later that decade, and with renewed vigour, the emphasis has swung towards the use of external facilitators to bring impartiality and expertise to the process.

The idea has a long and wide pedigree. The Toronto Stock Exchange recommended the evaluations for listed company boards as far back as 1994 (Cadbury, 1999). The New York Stock Exchange requires annual, internally conducted board and committee evaluations as part of its corporate governance guidelines (NYSE, 2014). Professional advisory firms in a variety of countries recommend it (e.g., in India; see Deloitte, 2014). Board evaluation became policy in the UK with publication of the version of the Combined Code (FRC, 2003) that followed the Higgs Review (2003). Initially the code urged annual evaluations in some form, and later (FRC, 2010) came a recommendation that external facilitators lead the process at least every three years, rather than relying only on internally conducted evaluations.

Directors acknowledge the value of evaluations, though with reservations. A survey by the accountancy firm PricewaterhouseCoopers (PwC, 2014) found that $91 \%$ of directors felt their self-evaluation programmes were at least somewhat effective, though $70 \%$ said they had trouble being frank.

Despite this wide interest from practitioners and policymakers, empirical research in board evaluation is still quite limited. The sensitivity of the subject matter, combined with much discussed problems of penetrating the "black box" of corporate boards (Zona and Zattoni, 2007), mean that access to both the process and outcomes of board evaluations is difficult.

This paper lifts that veil a little higher by exploring in-depth the attitudes of directors who have undergone the process of evaluation. Our concern is in understanding what participants in the process find to be the relative advantages and drawback of self-evaluation techniques and those when an external advisor leads the process. In doing so we illuminate questions concerning the purposes, timing and substance of each type and develop ideas for further research to substantiate these tentative findings. 
Our study contributes to our knowledge of board evaluations in the following ways: It shows acceptance, sometimes grudging, among directors that external evaluation of boards can add value by picking up on interpersonal dynamics that self-evaluation exercises seem to overlook. This acceptance validates that broad policy direction in codes and listing rules, in the UK and elsewhere, to mandate at least occasional use of external facilitators in larger firms. Acknowledgement of that value, even among companies that are not bound by such institutional or policy pressure, also points a likely demand for services, highlighting a need for a professionalisation of service providers, and for research to develop a better understanding of the overlaps, complementarities, and limitations of both board selfevaluation and exercises facilitated by outsiders.

The balance of the paper is organised as follows. To set the scene, we sketch the market and institutional context in which calls for board evaluation became so strong. We then review the growing but still modest literature on board evaluation, differentiating between normative and empirical studies to identify the limitations of current knowledge of the field. After a discussion of methods, we then report on interviews with 17 directors of a variety of companies operating broadly under the guidance of British law and regulation. All respondents are seasoned directors, most with multiple directorships totalling nearly 200 listed, private and subsidiary companies, and many undertook evaluations of both broad styles. We then discuss the implications of their views for the process of evaluation, identifying different functions the two types can serve and different processes they might follow, as well as avenues for further research.

Despite the limitations of this small-scale study, it offers reasons to question some of the well-intended policy prescriptions in recent years and to build evidence for future policymaking. In so doing, it provides a basis for thinking that boards might use more extensively the discretion they have under the "comply-or-explain" provisions of codes like the UK Corporate Governance Code to experiment with other approaches to board evaluation.

\section{Market and institutional context}

Poor board performance has long been mooted as the source of corporate governance lapses. Agency theorists identified lax controls on senior management as contributing to both the rises in executive pay and the lack of concentration of shareholder value in the 1970s, especially in the United States (Eisenhardt, 1989;Fama, 1980;Ross, 1973). This theorising 
led to normative conclusions including stronger and more independent boards of directors and greater shareholder scrutiny (Roe, 1994;Bebchuk and Fried, 2003). Professional bodies, including the National Association of Corporate Directors in the US (NACD, 2001), and stock exchanges like Toronto recommended some form of board appraisal to safeguard against lazy directors (Leblanc, 2002). Nonetheless such urging met with considerable resistance among directors (Ingley and van der Walt, 2002).

The collapse of major corporations, particularly but not exclusively in the US, in the 2000-2002 period led to policy demands for action. In a widely copied initiative in the UK, the government-sponsored Higgs Review (2003) recommended annual, formal evaluations of the board as a whole, committees, and individual directors, adding that using outside facilitators "can bring objectivity" (2003). As incorporated in a new version of the Combined Code (FRC, 2003), the recommendation became one of annual evaluations but the main body of the code did not mention external facilitation. These provisions were subject to the voluntary "comply-or-explain" regime in UK corporate governance. Uptake was initially tentative.

That changed, however, after the financial crisis of 2007-2009, in which one small bank was nationalised and two large ones part-nationalised. One of the large ones, the Royal Bank of Scotland, had transformed itself through aggressive national and international acquisitions into the largest bank in the world. Its failure shook policymakers into actions (FSA, 2011) which included a new UK Corporate Governance Code (FRC, 2010) that urged annual evaluations and externally-led ones at least once every three years. Acceptance of these provisions grew steadily (cf. Grant Thornton, 2011, 2016).

The UK policy move caught the spirit of the time, and authorities in many jurisdictions put pressure on corporate boards to undertake some form of self-assessment or use external consultants to examine the performance of boards, committees and individual directors. In contrast to the widespread interest in practice and policy, the subject has received relatively little scholarly attention and even less empirical research.

\section{Board evaluation theory and evidence}

Boards work as groups, and, despite the efforts of directors to keep their deliberations as rational as possible, emotions often get involved (Bodolica and Spraggon, 2011;Brundin and Nordqvist, 2008). Issues of group psychology arise, including groupthink (Janis, 
1972;Maharaj, 2008), which can cast doubt over the quality of self-perception and awareness (Bollich, Rogers and Vazire, 2015;Church, 1997;Duval and Lalwani, 1999).

Moreover, boards are notoriously difficult to research. They deal with confidential material, often of a commercially sensitive nature. They are populated by business elites more accustomed to giving rather than receiving appraisals, let alone having researchers examine them in the process. The "black box" of the boardroom is a phrase used in studies (Huse, 2005;Leblanc and Schwartz, 2007;Rost and Osterloh, 2010;Zona and Zattoni, 2007) to explain why more rigorous information collection is not possible.

As a result, and despite the importance of the topic in practice and public policy, the literature on board evaluation is still at an early stage of development. ${ }^{1}$ Even now much of what we find in academic journals is practical advice, rather than detailed analysis or theorising.

One of the earliest publications came from Conger, Finegold and Lawler (1998), who argued in the practitioner-oriented Harvard Business Review that appraising the board can improve board/management relations. Their assertions arose from interviews with directors at a dozen companies they termed pioneers of the practice.

An early scholarly analysis came from van der Walt and Ingley (2000), who identified differences in approach in New Zealand between inside, executive directors and external, non-executives, examining factors they saw as important in assessing board effectiveness. Ingley and van der Walt (2002) went on to identify the political aspects of board evaluation, including why some boards undertook evaluations but also reasons for their resistance to evaluation processes. Among their concerns was a fear the process would upset the cohesion and trust needed for the board to function well. Schaffer (2002) analysed how executives and non-executives came to very different interpretations of the same events, with executives more likely to attribute business setbacks to environmental forces than non-executives. While not explicitly a study of board evaluation per se, the distinction they found in the views of the two director-types draws attention to director bias, one of the arguments made for externally led evaluations.

Minichilli, Gabrielsson and Huse (2007) developed a schema for the evaluation process, including identifying four "building blocks" of a system, comprising who conducted the evaluation; what its content should be; to whom it is addressed, that is, whether it is focused on internal improvements or had external audiences; and how the process unfolds in practical terms. This logical schema is helpful in suggesting ways practitioners can 
undertake the process, though it stops short of providing an evidence base about the effectiveness of the approach.

A broad overview of the topic by Nicholson, Kiel and Tunny (2012) shows wide institutional support in Asia, Europe and North America for board evaluation, mainly through codes of corporate governance, most annually and some "regularly". At the time of their data collection, the UK was the only country listed that specifically recommended external facilitation; this has now grown to more than 15 countries. Their book chapter shows wide practitioner interest in the practice, with a list of tools and checklists for board evaluation in use as early as 1991.

They also note that a "major criticism of external reviews is that they rely on the published statements of companies" (Nicholson et al., 2012). While it is clear that some companies commission reviews from corporate governance ratings firms as "external" sources, our experience of the practice in the UK and other territories that have followed its lead is that most consider external facilitation to involve a consultant involved in interviewing directors and observing board and committee meetings. These interventions are relatively expensive, which, as we will see, can be a concern to directors, and can produce reports containing much sensitive, qualitative information.

Such overview studies highlight a range of options to be considered in designing board evaluation processes. Another stream of the literature takes a normative stance, arguing for certain variations and against others. In their study of board effectiveness and team production in small firms, Machold, Huse, Minichilli and Nordqvist (2011) suggest that board evaluations can be powerful tools for board development. But that is an assertion, not a direct outcome of their empirical work. Long (2006) draws on her experience as a practitioner of externally led evaluations to present a rounded view of the process options that highlight circumstances in which an outside facilitator can be helpful. Kiel and Nicholson (2005) provide a practical guide to board evaluation and a framework for doing it.

The literature also shows anecdotal evidence of directors' scepticism that consultants hired as external facilitators will have the insights necessary to understand the business or to get behind the façade the directors and boards may construct. In a provocative analysis, Wiersema and Zhang (2011) view board evaluation through a sideways study examining the disciplinary role that analyst interventions play in CEO dismissals. Based on those results, they argue that investment analysts, rather than human resources specialists or board consultants, may be better external evaluators of board and executive performance. 
Direct empirical work in the field is limited. While a handful of studies view board evaluation in narrow context, including sustainability actions (Aly and Mansour, 2017), family business (Vandebeek, Voordeckers, Lambrechts and Huybrechts, 2016), or assessment of board committees (Martinov-Bennie, Soh and Tweedie, 2015), none of these documents the benefits and drawbacks of internally guided and externally facilitated evaluations, as seen from the point of view of directors themselves.

In terms of outcomes, Dulewicz and Herbert (2008) undertook a survey involving 29 company secretaries from among the top 350 companies listed in the UK (FTSE350), finding that among the outcomes of the process can lead to significant changes of board personnel. Evaluations contributed to the resignation of directors in nearly a third of the cases, while gaps identified influences appointments of new directors even more frequently (cited in Nicholson et al., 2012).

Rasmussen (2015) went further in a multiple case study analysis that raises questions whether board evaluation can measure the effectiveness, as it sets out to do. Her study shows evidence of the internal politics cited by Ingley and van der Walt (2002) and Schaffer (2002). It also calls attention to externally focused purposes of evaluation; while meant to enhance board accountability, evaluation can lead to political behaviour during evaluation and reporting about it.

The literature we reviewed is also largely silent on other aspects of the circumstances under which evaluations take place. The policy initiative in the UK in particular seeks annual evaluations and externally facilitated ones at least every three years. But that would seem to lead to a schedule of appraisal based on arbitrary timing, rather than on the circumstances of the company and the nature of decisions a board might face. Boards might well schedule appraisals for quiet times, when the chance of challenge and heated debate is low and the chance of dysfunctional behaviour is limited. The literature also gives little insight about the conduct of evaluation - where it takes place, using what methods of data collection for which types of insights.

This review of the literature points, therefore, to a large number of questions that need to be addressed to achieve the evidence-base required for appropriate corporate decisions about when, how and why to conduct appraisals. It also poses questions about how well suited regulation and public policy recommendations are to the issues they seek to address. This study makes an inroad in these questions by exploring the experiences and attitudes of directors of a range of companies working in jurisdictions broadly under the umbrella of UK institutions and practices: Britain itself and the Channel Islands territories where much 
financial services activity takes place and where the authorities have been keen to press for high standards of corporate governance. We discuss the sample and other methodological considerations next before presenting the findings of this inquiry.

\section{Methods}

To uncover attitudes towards board evaluation and in particular towards the use of external facilitators, our research involved a three-stage process. In the first phase, we identified a range of individuals capable of providing insight into the processes of board evaluation. The sample was derived from amongst the contacts of the lead researcher, a professional working in the financial services industry in the British Channel Islands whose role brought contact with directors, particularly in the finance sector. These contacts were sent a questionnaire that set the scene of the study and primed respondents to consider issues of board evaluation as well as establishing the level and range of experience they had with the process. The process identified 17 individuals with experience as non-executive directors ranging from two years to 40 years. Together they hold 50 listed company directorship appointments, either as chair, committee chair or non-executive and almost 200 in a range of company-types within the finance sector from investment companies to banking. They divided into two groups: Those with experience of external facilitation and those who had undergone only board self-evaluation exercises. Of the 17 individuals, all had participated in annual self-evaluation process in varying forms; eight had experienced external evaluation and between them had undertaken 20 such exercises, three while serving as directors of FTSE350 companies.

The second-phase involved semi-structured interviews conducted by the lead researcher of each of the 17 individuals ranging from 60 minutes to 90 minutes in length, using the questionnaire to prompt the line of enquiry. The interviewees were encouraged to discuss their considerations as to strengths and weaknesses of the processes of each self-evaluation and external evaluation. Where individuals had no direct experience of external evaluations their thoughts towards the process were not discounted as these contributed to the overall understanding of policy implementation. The interviews were recorded and transcribed, and after iterative reading of the transcriptions, sections of the texts were categorised as positive and negative attitudes towards both evaluation processes.

The categories chosen in the first instance included descriptive terms drawn from the literature, including director attitudes towards a) the concept of and policy emphasis on 
board evaluation, b) the benefits and shortcomings of internally orchestrated and externally facilitated evaluations, and c) the outcomes of the processes. In a second iteration of analysis, we assessed another theme that emerged during the interviews, d) the frequency of evaluation.

The third phase involved boardroom observation of five stock exchange-listed companies on which the 17 directors are appointed. Four of these involved the annual selfevaluation; the fifth was for a company undergoing external evaluation process. Each of the four company boards undertook the same self-evaluation process with a questionnaire completed individually by each of the board members and the results collated into a report and discussed in a boardroom setting. The external evaluation process included individual interviews between the external evaluation facilitator the directors and the company secretary, a review of board packs, and boardroom observation. The process culminated with a report on results, which was then discussed by the board. This board report was provided to us for this study. Implementation of suggested changes was then discussed between the lead researcher and the chairman.

Whilst the size of this exploratory study is too small to form the basis for generalisation, the study provides insight into the use of policy within the finance sector and contributes to understanding of the implementation and application of the safe-guarding measure of evaluation adopted by the regulator as a response to corporate failings. None of the companies involved is part of the FTSE350, which are subject to the recommendation of the UK Corporate Governance Code. Nonetheless, they engage in board evaluations as a matter of best practice, a sign of the growing practical significance of the process and how the policy has spread its influence to wider sections of the corporate landscape.

\section{Findings}

Central to issue of evaluation is directors' attitudes towards the process and the policy, which will help to understand reasons for commitment to or resistance against the policy direction. We then look specifically at the emerging policy approach by considering attitudes towards self-assessment and external facilitation, before considering views of the outcomes of the process. Because of concern in UK policy, and elsewhere, about the frequency and scheduling of externally facilitated evaluations, we include a section on this theme in presenting our findings. 


\section{Attitudes towards evaluation and policy}

Since its revision in 2010, the UK Corporate Governance Code has recommended that boards of large listed companies (i.e., the FTSE350) implement the annual board evaluation, and that external facilitators conduct them at least every three years. A quotation reflects the view of many of the participants:

Director 14: Reassessment is imperative.... If there isn't evaluation ... then there's a risk you end up repeating mistakes or settling into bad habits and we know in business also that can result in the failure of the business especially at the board level.

The directors in our study were not bound by this guidance, but in general they recognised the importance of the process. Nonetheless, two of the five companies had voluntarily implemented the above and a further company would be undertaking an external evaluation in the near future. The value placed on the option to undertake an evaluation with an external consultant was explained as:

Director 6: The external board evaluator [is] there as an outside professional as you would use a lawyer or an accountant.... And it's good from time to time to have somebody say: "Well actually you could do a bit better if you did it that way." Everybody can improve.

Most felt that the external evaluation prescribed timing in the UK Corporate Governance code of every three years was acceptable even for smaller companies, outside of the FTSE350; however, some felt the cost implication was prohibitive for their smaller boards.

For each method available to the boards to gather the qualitative data for understanding their performance, weaknesses and strengths, being annually through a questionnaire or through an external consultant, we reviewed the prevailing and pertinent perceptions of the participants to identify benefits and disadvantages of each method.

\section{Self-evaluation vs external facilitation}

When undertaking self-evaluation, each board employed a questionnaire covering a range of topics: board composition, meeting process, board information, training, board dynamics, accountability, and effectiveness, as well as an evaluation of the leadership qualities of the chair. The questionnaires asked the directors to rate one to three on the topics under review, with the lowest number relating to the director considering that improvement was required and the highest that no improvement was necessary. The majority of questions resulted in the directors scoring the highest score with no lowest scores given. Where directors did provide an average score comments were requested and some provided as to 
why they considered more improvement was required. All results were put into a report to form the basis of the boardroom discussion.

Some of the directors worried, however, that the use of a questionnaire format might lead to responses that were less than open and honest:

Director 5: You don't have to give sufficient justification for your reasoning in the scoring exercise, so you don't expose yourself to actually showing deficiencies.... We've done our job, we can't be criticised too much, we're ok, we've thought about it, now move on.

Director 6: [You] can have situations when people aren't particularly honest and they want to duck the issue ... [which can make selfevaluation] a complete waste of time.

Director 10: Board members are not necessarily going to say precisely what they think.

This negative attitude towards honesty in the self-evaluation process was particularly associated with providing criticism of fellow directors: One of the directors explained it in these terms:

Director 13: We tend to be defensive and we'll tend to ... look for people to reinforce our own belief of our competence than actually criticise.

However, the directors considered that the process could be improved with the application of open and honest responses to the questionnaire and a serious approach to the process:

Director 8: [Self-]evaluation has the capacity to be very helpful, but obviously it's very reliant on how seriously people take it.

Director 11: [We need] a board that will say what it thinks as opposed to what it thinks it ought to say.

Where directors did not consider the self-evaluation process of benefit, it was mostly when they felt there were no issues that needed to be raised. One explained that:

Director 10: It's a pain in the neck.... If you have a board that works well together it's very easy to do, but it's always an additional burden on the board.

Where directors were engaged with the process, the predominant benefit was that of providing time to consider their contribution to the board, the use of their skills in the boardroom, to allow for board composition considerations with a balance of skills and knowledge and as a group the weaknesses and behaviour which needed improvement:

Director 1: A board that conducts proper evaluation is more confident in its behaviour and in its discharging of its duties. 
Director 3: Without the process, you've got no way of formally identifying weaknesses.

The need for open and honest evaluation was acknowledged as existing not only for the improvement of the performance of the board and company but also at a personal level for the directors. The poor performance of the board not identified through evaluation could ultimately lead to company failure or regulatory issues for which the individual board director would be culpable under their fiduciary duty:

Director 8: Very few people see it as constructive, but the people who've looked at it as constructive tend to be a certain type of person who really understands the risk they're personally taking.

The directors suggested that to increase the value of the self-evaluation process the design of the evaluation questionnaire needed to focus on company specific attributes and events as well as general questions for the directors to consider.

The directors also suggested performance appraisal of the board from management and the company secretary, a variation on the theme of 360-degree appraisals that have become increasingly common in human resources management since the 1990s (Atwater and Waldman, 1998), though not without controversy (Waldman, Atwater and Antonioni, 1998). Each of the boards in our study discussed the results of their self-evaluation in a boardroom setting with no others present other than the company secretary.

In all evaluation results, no criticism towards the performance of the board or chair was recorded, and in the open discussions no directors disclosed any inter-relational dynamics issues or board culture or environment changes they deemed necessary. The reluctance to include any comments in the self-evaluations do not appear to be specific to the boardroom observations as part of the study, evidenced with:

Director 9: These evaluations have not really resulted...in [a] change in behaviour, individually and collectively, but it should.

Director 12: Bringing problems out into the open can be a double-edged sword. You can fix them sometimes but you can also create animosity which doesn't go away.

The boardroom discussions mainly focused on external relationships to the board itself, calling for information flow to the board to be increased in relation to their oversight role, for example, to monitor the actions of the managers and to be kept up-to-date with regulatory changes. The chair or the company secretary agreed to implement the improvements required. 
Mostly the process of self-evaluation was valued as a tool for improvement when the process was working well and engagement from all directors was apparent. Where the directors that tended to consider that their self-assessment was working well or for a few where they felt they were experienced board members, little requirement for an external evaluator was seen:

Director 3: When you've got the vast experience...it would be total overkill to do it.

Although it was more recognised that the external evaluator can assist to obtain in-depth opinions and valuable information more so than the self-evaluation:

Director 5: [The external evaluator] might get down to the truth in more detail.

Director 9: If we have a good questionnaire, and we have honest participants and constructive answers, as far as the exercise of asking the questions and getting the answers, internal or external doesn't make much difference..... but where the external board evaluator can provide a more robust assessment would be where they might dig in a bit more.

Some directors stated that they would not want to speak openly with the evaluator about issues they see as only relevant for the board or chair to deal with and also would not wait until an evaluation to do so:

Director 12: There are issues that I would rather bring up directly with the board and not involve a third party.

Director 6: I think it'd be far more likely if there ... were really bad dynamics... individuals involved would speak to the chair...rather than waiting for board evaluation.

In contrast, there may be issues that only can be discussed with an independent third party:

Director 2: In the case of boards that may be dominated by one person...outside influence might be useful.

Although there were directors who had no experience of external evaluation, they contributed to the attitudes towards the process. They generally felt that they would be more open and honest with an external evaluator than they would in a self-evaluation questionnaire.

To obtain the honesty necessary for valid data collection, respondents said the external evaluator needs a) to be independent from the company under review, b) to be in possession of the necessary skills and experience to deem the results reliable, and c) to be trustworthy and discreet: 
Director 8: If there is any hint that they are not discreet then people are not going to speak to them openly and therefore the process won't be valuable.

The evaluator also needs d) to know how to deliver feedback to the board with a degree of diplomacy, whilst also being in possession of the necessary influence and impact for the board members to respect their evaluation results. One director suggested that the only way some boards would give respect to outsiders' suggestions for changes to their boardroom processes was if the evaluator acquired a status similar to that of a regulator:

Director 14: They [the board] are top of the tree; who's going to have an impact and influence over the individuals on the board? In finance only the regulator can perform that.

One of the largest concerns for the directors is that the evaluator would not understand the company, the history of the relational dynamics within the board, or misinterpret one-off observation either in or outside of the boardroom, or within interviews conducted by the evaluator. One director explained the misinterpretation of social interaction as follows:

Director 13: The reviewer came ... to the normal board dinner [and reported the board as] a bit too friendly [and queried] whether you could be confrontational with your fellow board members and also civil over a dinner table.

The directors were also concerned that the methodology they had experienced, in which the evaluator observed only one board meeting, would not provide a true picture of the dynamics within the boardroom. The modification of behaviour that took place whilst being observed was explained as:

Director 4: They [the other directors] felt they had to say something because they were being marked.

There may also be a possibility that the directors could be dominated and forced by the chair to perform for the evaluator, evidenced as:

Director 14: Just before the [evaluator] was invited into the room, [the chair] says, Look, I'll say a few things and I'm this sort of person, I expect this, I don't expect this and I just want to remind you....

Where directors have been involved in external evaluation, positive secondary consequences were experienced. They felt results of the external evaluation informed the next annual self-evaluation and improved the process. Also, the act of deciding to allow an external consultant to evaluate the board led to improvements in board processes ahead of beginning the evaluation: 
Director 4: [We] look at ourselves with our own self-evaluation and decide, do we think we could stand up to someone coming in and looking at us from the outside.

The substance of this quote points to the next issue of concern. If board evaluations are not just window-dressing, that is, not just designed to comply with a reporting requirement, then what matters at least as much as process is the outcomes of the evaluation, and whatever differential there may be between those conducted internally or with an external facilitator.

\section{Outcomes of board evaluations}

The directors in our study generally thought there were benefits to the external evaluation over self-evaluation. The results were, in general, found to be useful and interesting. Those that had been through the process felt the peer comparison to ascertain advice on best practice, made possible by the facilitator's detachment, was of high importance:

Director 15: Evaluation adds enormous value because they can benchmark the board against other boards.

Director 4: Someone else coming in with fresh eyes, fresh thoughts, whose seen other companies operating ... can see that's pretty good but have you thought of ...

Some experienced validation of the boards existing processes and performance which provide for increased confidence on the board:

Director 6: It's not all criticism.... It is an excellent exercise which can really show you that the board is being run properly, [and] that you are considering the right things.

Both groups of directors - those who had and had not been through the external evaluation process - said they placed greater value on the results of the external evaluation than that of the self-evaluation. It was felt the externally generated outcomes were taken more seriously. They were not only the advice from an expert, but because the advice had been sought and being paid for, the recommendations would be acted upon:

Director 7: If you have an external report the board has to do something about it because it is a formal document ... you would take it more seriously ... as a more balanced view.

Director 15: If you're paying someone to provide a service then it focuses your mind on actually achieving something in return for that investment. 
The directors wanted to receive in their reports from the external evaluator not only the results of the observation and the interviews but ideas and pointers as to how to improve their performance:

Director 6: When it's an external evaluation, there could be a list of tasks that we should do.

Director 10: If they can identify things that are missing and map against the [corporate governance] code and come up with proper suggestions, I think that can be quite helpful.

In contrast some felt the suggestions for improvement that had been received were not of significance, evidenced by this comment:

Director 13: Didn't give us any concrete points to change the board, there were a few comments we took on board, but it really didn't help.

The directors considered that there was benefit to employing an external evaluator, if the evaluator had the experience and approached the process to obtain significant suggestions for change that were at both the board and at an individual level to understand the board and the directors contribution:

Director 15: Are there behaviours that you as an individual are introducing....is the company successful despite your behaviour rather than because of it?

\section{Frequency of reviews}

In relation to the use of an external facilitator for board evaluation, directors were willing to extend the code's recommendation of external evaluators beyond the FTSE350:

Director 17: [External evaluation is] a source of best practice that even smaller companies should aspire to, so on that basis I wouldn't see any reason to remove something just because the company isn't big enough for FTSE350.

The frequency in the code was largely considered to be correct at three years, even for smaller companies, though with some reservations:

Director 14: Reassessment is imperative ... if there isn't evaluation ... then there's a risk you end up repeating mistakes or settling into bad habits and we know in business also that can result in the failure of the business especially at the board level.

Director 14: If you're just in a constant cycle of ... assessment ... you'll never anything done.

However, there was a concern over cost to meet the code when the board considered the necessity as not there: 
Director 11: The question I have is whether or not the cost is justified. There is a view that it should be done every three and I've spoken to investors and they get quite upset of the fact. If they feel that the Board is doing a good job, why should they have to cough up anything from GBP10,000 to GBP15,000 every three years when they're totally happy.

The flexibility of the code provides the ability to, where there were issues identified, the frequency of external evaluation could be reconsidered and evaluations conducted more as needs dictated, rather than according to a fixed schedule:

Director 17: When specific issues have been identified and there is room for improvement there shouldn't be any reason why there shouldn't be a follow-up with a further evaluation the next year.

But the frequency did need to be carefully considered and not just applied to meet the code with a suggestion that shareholders be invited to opine as to whether they would agree to the board being externally evaluated, which would allow for increased shareholder engagement and inversely shareholder accountability:

Director 11: I wonder whether or not it would be appropriate if a circular to all investors was done prior to an external Board evaluation and the cost incurred?

\section{Discussion}

The literature suggests that directors were initially reluctant to recognise the importance of evaluation, even though it had been identified in policy post-Enron, examined in theorising by Ingley and van der Walt (2002), and advocated for practice by Long (2006). Our inquiry, however, indicates that 10 years after the onset of the financial crisis, and after even firmer policy direction, directors' attitudes have transformed. They accept that evaluations have an important role in enhancing board performance. This acceptance has the indirect but important benefit of contributing to and ensuring company continuity beyond the current directors' tenure. Our research also validates an observation in Rebeiz (2016) that the benefits of evaluation depend on the commitment to the process by their fellow directors.

This shift to accept evaluation could be attributable to two main factors: high profile corporate governance failures and longevity of implementation. In the 2008 failure of the UK banking group HBOS Plc, investigation by the regulator uncovered boardroom behavioural dynamics that demonstrated that boards' actions and behaviours can directly affect company performance (Bank of England, 2015). It is worth noting that our research found little evidence that behavioural dynamics are discussed during a board's selfevaluation process, but external evaluators were sensitive to them. 
The second factor contributing to the attitude shift may be due to the longevity and frequency of the application of the requirements for evaluation under the UK code. The UK acceptance of evaluation is in contrast to a similar study of Norwegian corporate governance abiding companies by Rasmussen (2015), which may be attributable to the evaluation requirements of the Norwegian corporate governance code not specifying the frequency or necessity of annual or external evaluations. It would be interesting to look into the attitudes of different boards abiding to different corporate governance codes with differing evaluation guidance to ascertain whether this link between requirements and acceptance is general and valid.

Our respondents' attitudes towards evaluation carried out by an external consultant seemed to be shifting; they acknowledge the importance of their role, but acceptance is not universal. Directors in our study remained reluctant to accept that outsiders could understand the specific boardroom environment and identify and make valid suggestions for improved board performance. There was agreement that greater acceptance of the professionalism of the sector would be obtained with a code of practice (Pitcher, 2014). Such a draft exists; however, there is no regulatory backing and standardisation of the approach to evaluation practitioners has not yet been achieved.

The research uncovered difficulties in the process of self-evaluation as well. These were identified as lack of defined purpose ahead of commencing the evaluation; inability to identify dysfunctional behavioural dynamics; lack of independence to remain impartial and reluctance to voice concerns; and an inability to assess against peers. These deficits mean the results of self-evaluation are not a true reflection of the board environment. Importantly, evaluation results were not acted upon and very few suggestions for change were implemented.

Difficulties identified during self-evaluation may be overcome by employing an evaluation practitioner who has increased skills and experience that an internal reviewer may not possess (Kiel and Nicholson, 2005). However, this study suggests that process facilitators can contribute their own difficulties. Utilising an external evaluator brings a degree of independence and objectivity, but their work is still subjective and interpretivist, as in other ethnographic research.

This study shows that the self-evaluation processes we examined did not involve the initial purpose and extent of the evaluation, a starting point deemed relevant to add validity (Minichilli et al., 2007). This is in contrast to the examples of external evaluation our respondents described. As with other engagements of professional consultants, mandates 
given to external evaluators defined the purpose and extent of the exercise. Doing so provided relevancy to the results.

To overcome the difficulties in self-evaluation, the results suggest that external evaluators need the ability to identify and classify behavioural dynamics, the decisionmaking culture (Bailey and Peck, 2013;Huse, 2005;Samra-Fredericks, 2000), group psychology processes (Merchant and Pick, 2010), and the emotional energies in the boardroom (Brundin and Nordqvist, 2008). These are factors not generally included in selfevaluation; and, as Bollich et al. (2015) explain, they are difficult to detect by those directly involved.

In our research, directors said they had received no individual feedback during selfevaluations of boards, though in the cases of employee appraisals and group activities the human resources literature shows such individual reflection leads to improved performance (Church, 1997;Duval and Lalwani, 1999;London, Larsen and Thisted, 1999). Through interviews and boardroom observation, an external evaluator may be better placed to build a picture of the current performance of a board and individual directors, and to provide feedback on issue that need to be addressed. The independence afforded to them ensures that they are less inclined than in self-evaluation to perform errors of omission (Caputo and Dunning, 2005).

These results can form objectives for the following year (Conger et al., 1998;Rasmussen, 2015), which our research discovered were not always an outcome of the self-evaluation process but arose in particular where an external evaluation process had been undertaken. The evaluator can also assist the chair to facilitate the changes considered as necessary for a better functioning board, as part of the developmental function of evaluation (Rasmussen, 2015).

The identified internal and external evaluation weakness that the processes do not hold the board accountable for implementing the changes they consider to be relevant and necessary. Our findings also chime with research showing that board and group culture tends to come from the chair (McNulty, Pettigrew, Jobome and Morris, 2011;Neubauer, 1997) and where change was necessary the directors would look to the chair for implementation (Reicher, Haslam and Hopkins, 2005;Leblanc, 2005). This suggests that external facilitators can grow into somewhat larger roles that can enhance their understanding of the company and its special circumstances. With such increased involvement comes the risk they will gradually become insiders. If their role has the ability to influence change on the board much in the way a regulator can, as Director 14 suggested, then increasing involvement in 
implementation might increase the risk of a new form of regulatory capture (cf. Baxter, 2011).

Should boards be given greater flexibility over the timing of board evaluations, even more than the comply-or-exchange regime permits? Doing so might make them less tied to the reporting and less hostage to the tick-box mentality (FRC, 2012) that has become attached to the UK Corporate Governance Code in general, and to similar regimes in other countries. This study suggests, however, that directors welcome the prescribed frequency of once every three years because it reduces subjectivity and helps them overcome the priorities of their chair, especially when a domineering character holds the role. This level of comfort of prescribed external evaluation extends to shareholders insofar as an account of the evaluation is published in the accounts, allowing the shareholders to look beyond the company results and into the workings of the board. Although not part of this study, current reporting on evaluation is generally considered very basic and further research into evaluation disclosure to shareholders and stakeholders could be undertaken.

\section{Limitations and implications for research}

This is a small study of boards of mainly smaller companies, which makes it difficult to generalise the findings across the wide range of companies now engaging in board evaluation. However, the nascent literature on this field needs studies like this to frame the issues, understand the attitudes of directors, and see how those attitudes develop as they become increasingly familiar with the task. These observations suggest a variety of avenues for future exploratory and confirmatory research to help us stay abreast of the evolving practice and to inform further public policy initiatives.

Because research into board evaluation is at an early stage, we are still in need of identifying the right questions to ask before we can develop theories to explain how the process works and how it differs, for example, from employee performance management or the psychology of workgroups and project teams. Our study has detected some of the practices, but its scale is too small to suggest we have any more than scratched the surface of the full variety of ways in which boards conduct such activities.

We have seen evidence of questionnaire-based information gathering, of interviews and board observations that feed into the evaluation. We have seen evidence of group meetings to discuss the outcomes, and we heard of findings left undiscussed and unacted upon. Practice-level research, examining the artefacts and rituals of board evaluation, would give 
us better insights into how the process embeds itself, and what leads the process towards successful discovery or down the path to stale routine.

The literature suggests board evaluation is seen as a powerful and also a neglected tool in the quest for improved board and firm performance. The literature we reviewed provides much advice about conducting board evaluations, but little evidence. And just as the links between effectiveness and performance are complex, as Forbes and Milliken (1999) and those that followed it have described, the links between evaluation and effectiveness need exploration as well, so we can understand what factors matter.

The study gives us some pointers, however. Many of the antecedents, process elements, and outcomes that contribute to board effectiveness are coming to be understood, and enhanced disclosure is making data available to help assess, for example, the effort norms of boards and the balance of knowledge and skills on the boards. But the evaluation process, and the board evaluators themselves, gives insights into the interpersonal relations of directors, and to the characteristics of directors themselves, their traits and biases. Do directors exhibit, for example, the persuasiveness that Leblanc and Gillies (2005) associate with directors of successful boards, or the cultural intelligence (Earley, 2002) and sensitivity to other directors it seems to imply (Charas, 2015)? Understanding these factors might help boards and directors cope with the tensions between cognitive conflict and board cohesiveness that Forbes and Milliken (1999) highlight. It is difficult to gain access to study such matters in corporate boards, to be sure. Yet as a proxy, research might be conducted, confidentially and with great discretion, in public sector boards, where a greater inclination towards openness to external scrutiny is likely.

\section{Implications for practice and policy}

Our study also has implications for the practice of boards and evaluators, and for policy and regulation. We spoke with directors of mainly small companies, smaller than those at whom the policy of external evaluation is directed. They generally found something valuable in the process, in particular when an external evaluator was present and when that person was sufficiently grounded in the company's business to understand the nuances. This suggests something about the character and skills needed by board evaluators. Given the direction of travel in policy, the number of board evaluators seems set to rise.

The knowledge and skills of evaluators that seem so valued now may already be rather scarce, suggesting a need to develop new greater capabilities of evaluators as well as more 
capacity for board evaluation. Anecdotal evidence suggests that many large company boards have resisted the entreaties of large management consultancies, accountancy firms, and headhunters to fill the gap, preferring instead the help of boutique board evaluation firms. The practices they follow are less than fully understood, so understanding their approach to evaluation as well as boards may be important. Some of the suggestions in this study point to a role for a professional body to certify evaluators and thus provide the trust identified directors require. This acceptance by boards of the experience and qualification of evaluators would then lead to acceptance of the evaluation results and implementation of improvement suggestions. In the meantime, even our modest study suggests a need for the professionalisation of practice, and with it some certification, if not perhaps standardisation.

There is a danger - evident in the literature as well as in the undercurrent of our directors' thinking - that the routinisation of board evaluation may induce what Westphal and Zajac (1998) call the symbolic management in corporate relations with the shareholders, that is, the manipulation of compliance tasks and disclosure to misrepresent activities undertaken. Corporate governance ratings firms already target board evaluation reporting as an element in their compliance rankings. Such metrics have worked their way into the portfolio management exercises of asset management firms and into the interrogation of directors by investment analysts and those engaged in monitoring environmental, social, and governance (ESG) issues. The impact for public accountability for private conversations looms large in this field, and we understood, as yet, so little about it. The chances for unintended consequences from policy decisions need careful thought. Would further disclosure on the inner workings of the board lead to smaller, currently out-of-scope firms choosing not to implement what is starting to be seen as best practice? And if so would they be missing out on the opportunity to obtain professional advice as to become more effective decision-making groups?

\section{Conclusions}

Board evaluation is clearly an important topic, with value for practitioners, policymakers, and researchers. But it is also one that is difficult to research empirically. This study contributes to our understanding by exploring the attitudes of directors who have undertaken multiple board evaluations and experienced the benefits from having done so. It suggests sometimes grudging acceptance of the value of externally facilitated exercises, in particular for their ability to detect the dynamics of director interactions to achieve increased 
performance to which self-evaluation seems structurally blind. The directors in our study acknowledged both social sensitivity and industry- and firm-specific understanding as important criteria to generate value from the exercise and trust in the evaluator.

Further research is needed, therefore, to understand what parts of the process are largely independent of such industry- and firm-level knowledge to add value. Doing so would help practitioners develop the skills needed to meet the growing demand for external facilitation that seems inevitable from the policy direction. This study points us towards developing greater understanding of the interplay between the social characteristics of directors, the dynamics of the boardroom that result from them, and how those dynamics contribute to board effectiveness, that is, to open the black box a crack. Given the difficulties of conducting board research, the developing practice of board evaluation may shed light on that darkness.

\footnotetext{
${ }^{1}$ After a more general search for literature on board evaluation and related terms using Google and EBSCO Business Source Complete, we undertook a targeted search of the Scopus database for the phrases "board evaluation" or "board apprais" or "board assessm" in title, abstracts or keywords of articles, conference papers and book chapters in business and management. These three terms have come to be the standard ones used in academic discussion of the practice. It yielded just 40 papers, the first in 1987 and running until the end of 2016. After filtering for relevance, only 29 papers remained, the earliest from 1997, and just 13 were empirically based, whether quantitative or qualitative in approach. This paper draws upon those and our wider searches to include other key studies, articles in professional journals and papers by consulting firms to achieve a more rounded view. Nonetheless the narrowness of the literature demonstrates the limited scholarly attention board evaluation has received to date.
} 


\section{References}

Aly, A. H. and M. E. Mansour (2017). 'Evaluating the sustainable performance of corporate boards: the balanced scorecard approach', Managerial Auditing Journal, 32, pp. 167-195.

Atwater, L. and D. Waldman (1998). '360 Degree feedback and leadership development', The Leadership Quarterly, 9, pp. 423-426.

Bailey, B. C. and S. I. Peck (2013). 'Boardroom Strategic Decision-Making Style: Understanding the Antecedents', Corporate Governance: An International Review, 21, pp. 131-146.

Bank of England (2015). 'The Failure of HBOS plc'. UK Financial Conduct Authority and Prudential Regulatory Authority report. London: Bank of England.

Baxter, L. G. (2011). 'Capture in Financial Regulation: Can We Channel It toward the Common Good', Cornell Journal of Law and Public Policy, 21, pp. 175-200.

Bebchuk, L. A. and J. M. Fried (2003). 'Executive Compensation as an Agency Problem', Journal of Economic Perspectives, 17, pp. 71-92.

Bodolica, V. and M. Spraggon (2011). 'Behavioral Governance and Self-Conscious Emotions: Unveiling Governance Implications of Authentic and Hubristic Pride', Journal of Business Ethics, 100, pp. 535-550.

Bollich, K. L., K. H. Rogers and S. Vazire (2015). 'Knowing More Than We Can Tell', Personality and Social Psychology Bulletin, 41, pp. 918-929.

Brundin, E. and M. Nordqvist (2008). 'Beyond Facts and Figures: The Role of Emotions in Boardroom Dynamics', Corporate Governance: An International Review, 16, pp. 326341.

Cadbury, A. (1999). 'What are the trends in corporate governance? How will they affect your company?', Long Range Planning, 32, pp. 12-19.

Caputo, D. and D. Dunning (2005). 'What you don't know: The role played by errors of omission in imperfect self-assessments', Journal of Experimental Social Psychology, 41, pp. 488-505.

Charas, S. (2015). 'Improving corporate performance by enhancing team dynamics at the board level', International Journal of Disclosure and Governance, 12, pp. 107-131.

Church, A. H. (1997). 'Managerial Self-Awareness in High-Performing Individuals in Organizations', Journal of Applied Psychology, 82, pp. 281-292.

Conger, J. A., D. Finegold and E. E. Lawler, III (1998). 'Appraising boardroom performance', Harvard Business Review, 76, pp. 136-148.

Deloitte (2014). 'Performance Evaluation of Boards of Directors'. A client briefing note from Deloitte Touche Tohmatsu India. London.

Dulewicz, V. and P. Herbert (2008). 'Current practice of FTSE 350 Boards concerning the appointment, evaluation and development of directors, boards and committees post the Combined Code', International Journal of Business Governance and Ethics, 4, pp. 99115.

Duval, T. S. and N. Lalwani (1999). 'Objective Self-Awareness and Causal Attributions for Self-Standard Discrepancies: Changing Self or Changing Standards of Correctness', Personality and Social Psychology Bulletin, 25, pp. 1220-1229.

Earley, P. C. (2002). 'Redefining interactions across cultures and organizations: Moving forward with cultural intelligence', Research in Organizational Behavior, 24, pp. 271299.

Eisenhardt, K. M. (1989). 'Agency Theory: An Assessment and Review', Academy of Management Review, 14, pp. 57-74. 
Fama, E. F. (1980). 'Agency Problems and the Theory of the Firm', Journal of Political Economy, 88, pp. 288-307.

Forbes, D. P. and F. J. Milliken (1999). 'Cognition and corporate governance: Understanding boards of directors as strategic decision-making groups', Academy of Management Review, 24, pp. 489-505.

FRC (2003). 'Combined Code on Corporate Governance'. UK Financial Reporting Council. UK Financial Reporting Council.

FRC (2010). 'The UK Corporate Governance Code'. UK Financial Reporting Council. London: UK Financial Reporting Council.

FRC (2012). 'What constitutes compliance under 'Comply or Explain'? Report of discussions between companies and investors'. UK Financial Reporting Council. London: UK Financial Reporting Council.

FSA (2011). 'The Failure of the Royal Bank of Scotland plc'. UK Financial Services Authority report. London: UK Financial Services Authority.

Grant Thornton (2011). 'Corporate Governance Review 2011 - A changing climate, fresh challenges ahead'. London: Grant Thornton LLP.

Grant Thornton (2016). 'Corporate Governance Review 2016'. A publication of Grant Thornton UK LLP. London.

Higgs, D. (2003). 'Review of the Role and Effectiveness of Non-Executive Directors'. London: UK Department of Trade and Industry.

Huse, M. (2005). 'Accountability and Creating Accountability: a Framework for Exploring Behavioural Perspectives of Corporate Governance', British Journal of Management, 16, pp. S65-S79.

Ingley, C. B. and N. van der Walt (2002). 'Board Dynamics and the Politics of Appraisal', Corporate Governance: An International Review, 10, pp. 163-174.

Janis, I. J. (1972). Victims of Groupthink: A psychological study of foreign policy decisions, Houghton Mifflin, Boston.

Kiel, G. C. and G. J. Nicholson (2005). 'Evaluating Boards and Directors', Corporate Governance: An International Review, 13, pp. 613-631.

Leblanc, R. (2002). 'Assessing Board Performance: 10 Key Factors', Corporate Board, 23, pp. 1-6.

Leblanc, R. (2005). 'Assessing Board Leadership', Corporate Governance: An International Review, 13, pp. 654-666.

Leblanc, R. and J. Gillies (2005). Inside the Boardroom: How boards really work and the coming revolution in corporate governance, John Wiley \& Sons, Canada, Mississauga, Ont.

Leblanc, R. and M. S. Schwartz (2007). 'The Black Box of Board Process: gaining access to a difficult subject', Corporate Governance: An International Review, 15, pp. 843-851.

London, M., H. H. Larsen and L. N. Thisted (1999). 'Relationships between Feedback and Self-Development', Group \& Organization Management, 24, pp. 5-27.

Long, T. (2006). 'This Year's Model: influences on board and director evaluation', Corporate Governance: An International Review, 14, pp. 547-557.

Machold, S., M. Huse, A. Minichilli and M. Nordqvist (2011). 'Board Leadership and Strategy Involvement in Small Firms: A Team Production Approach', Corporate Governance: An International Review, 19, pp. 368-383.

Maharaj, R. (2008). 'Corporate governance, groupthink and bullies in the boardroom', International Journal of Disclosure and Governance, 5, pp. 69-92.

Martinov-Bennie, N., D. S. B. Soh and D. Tweedie (2015). 'An investigation into the roles, characteristics, expectations and evaluation practices of audit committees', Managerial Auditing Journal, 30, pp. 727-755. 
McNulty, T., A. Pettigrew, G. Jobome and C. Morris (2011). 'The role, power and influence of company chairs', Journal of Management \& Governance, 15, pp. 91-121.

Merchant, K. A. and K. Pick (2010). Blind Spots, Biases, and Other Pathologies in the Boardroom, Business Expert Press, New York.

Minichilli, A., J. Gabrielsson and M. Huse (2007). 'Board Evaluations: making a fit between the purpose and the system', Corporate Governance: An International Review, 15, pp. 609-622.

NACD (2001). 'NACD Blue Ribbon Commission on Board Evaluation: Improving director effectiveness'. National Association of Corporate Directors \& Center for Board Leadership. Washington: National Association of Corporate Directors.

Neubauer, F. (1997). 'A Formal Evaluation of the Chairman of the Board', Corporate Governance: An International Review, 5, pp. 160-165.

Nicholson, G., G. C. Kiel and J. A. Tunny (2012). 'Board evaluations: Contemporary thinking and practice'. In: T. Clarke and D. Branson (eds.), The Sage Handbook of Corporate Governance. pp. 285-324. London: Sage.

NYSE (2014). 'NYSE: Corporate Governance Guide'. New York: New York Stock Exchange.

Pitcher, H. (2014). 'Who evaluates the evaluators?'. Governance Newsletter. pp. 8-9. Governance Publishing \& Information Services Ltd.

PwC (2014). 'Trends Shaping Governance and the Board of the Future'. PwC's 2014 Annual Corporate Directors Survey. New York: PricewaterhouseCoopers.

Rasmussen, J. (2015). 'Do Board Evaluations Measure Board Effectiveness?', International Studies of Management \& Organization, 45, pp. 80-98.

Rebeiz, K. S. (2016). 'Design guidelines for boardroom's effectiveness: the case of Fortune 500 firms', Corporate Governance: The international journal of business in society, 16, pp. 490-506.

Reicher, S., S. A. Haslam and N. Hopkins (2005). 'Social identity and the dynamics of leadership: Leaders and followers as collaborative agents in the transformation of social reality', The Leadership Quarterly, 16, pp. 547-568.

Roe, M. J. (1994). Strong Managers, Weak Owners: The Political Roots of American Corporate Finance, Princeton University Press, Princeton.

Ross, S. A. (1973). 'The Economic Theory of Agency: The Principal's Problem', American Economic Review, 63, pp. 134-139.

Rost, K. and M. Osterloh (2010). 'Opening the Black Box of Upper Echelons: Drivers of Poor Information Processing During the Financial Crisis', Corporate Governance: An International Review, 18, pp. 212-233.

Samra-Fredericks, D. (2000). 'An Analysis of the Behavioural Dynamics of Corporate Governance: A talk-based ethnography of a UK manufacturing 'board-in-action", Corporate Governance: An International Review, 8, pp. 311-326.

Schaffer, B. S. (2002). 'Board assessments of managerial performance: An analysis of attribution processes', Journal of Managerial Psychology, 17, pp. 95-115.

van der Walt, N. and C. Ingley (2000). 'Evaluating board effectiveness: The changing context of strategic governance', Journal of Change Management, 1, pp. 313-331.

Vandebeek, A., W. Voordeckers, F. Lambrechts and J. Huybrechts (2016). 'Board role performance and faultlines in family firms: The moderating role of formal board evaluation', Journal of Family Business Strategy, 7, pp. 249-259.

Waldman, D. A., L. E. Atwater and D. Antonioni (1998). 'Has 360 degree feedback gone amok?', The Academy of Management Executive, 12, pp. 86-94. 
Westphal, J. D. and E. J. Zajac (1998). 'The Symbolic Management of Stockholders: Corporate Governance Reforms and Shareholder Reactions', Administrative Science Quarterly, 43, pp. 127-153.

Wiersema, M. F. and Y. Zhang (2011). 'CEO Dismissal: The role of investment analysts', Strategic Management Journal, 32, pp. 1161-1182.

Zona, F. and A. Zattoni (2007). 'Beyond the Black Box of Demography: board processes and task effectiveness within Italian firms', Corporate Governance: An International Review, 15, pp. 852-864. 